\title{
Ultrasonographic and radiographic determination of egg development of jurarás (Kinosternon scorpioides) in captivity ${ }^{1}$
}

\author{
Francisco B. Costa ${ }^{2 *}$, Flavio R. Alves ${ }^{3}$, Andréia P. Costa ${ }^{4}$, Ana C.E. Barros ${ }^{2}$, \\ Porfírio C. Guerra ${ }^{5}$, Alana L.Sousa ${ }^{5}$ and Antônia S. Oliveira ${ }^{5}$ \\ ABSTRACT.- Costa F.B., Alves F.R., Costa A.P., Barros A.C.E, Guerra P.C., Sousa \\ A.L. \& Oliveira A.S. 2009. Ultrasonographic and radiographic determination of egg \\ development of jurarás (Kinosternon scorpioides) in captivity. Pesquisa Veterinária \\ Brasileira 29(10):841-846. Departamento das Clínicas, Universidade Estadual do \\ Maranhão, Cidade Universitária Paulo VI, Tirirical, Cx. Postal 9, São Luís, MA 65055- \\ 310, Brazil. E-mail: franc.borges@yahoo.com.br \\ Kinosternon scorpioides (Linnaeus, 1766), with its common name of jurará, is a quite \\ variable species of turtles, and many different names have been applied to populations \\ throughout its range. Currently, however, four subspecies are considered valid as $K$. scorpioides \\ arises from southern Panama over most of northern South America and is found in Ecuador, \\ northern Peru, southern Bolivia, northern Argentina, eastern Guyana and Brazil. Thus, an \\ ultrasonographic and radiographic study was performed in order to describe the morphology \\ and development of eggs of 20 female jurará mud turtles $K$. scorpioides, from September \\ 2005 to August 2006. In the first month, the ovarian cycle was characterized by absence of \\ vitellogenic follicles, atresic follicles or oviduct eggs. From October 2005 to March 2006 on, \\ ultrasonographic scanning allowed to establish the growing vitellogenic follicles. Vitellogenic \\ follicles were observed with spherical to ovoid shapes, with a surrounding echogenic yolk, a \\ nonechogenic albumin layer, and a high echogenic shell. The oviduct eggs were identified by \\ radiography just 180 days after beginning the experiment, when the shell became enough \\ mineralized to impress the radiographic film. This experiment allowed to obtain by means of \\ the $7.5 \mathrm{MHz}$ linear probe images with adequate resolution and penetration for visualization of \\ follicles. Successive ultrasonographic examinations of $20 \mathrm{~K}$. scorpioides females allowed to \\ access initial stages of vitellogenic follicles and oviduct eggs, and radiographic examination \\ revealed to be an easy technique to assess oviduct eggs and to allow evaluation of egg \\ development in jurarás, from 6 months on.
}

INDEX TERMS: Kinosternon scorpioides, jurará, mud turtle, wildlife, conservation, reproduction.

RESUMO.- [Determinação ultrassonográfica e radiográfica do desenvolvimento de ovos de jurarás em cativeiro.] A tartaruga Kinosternon scorpioides (Linnaeus, 1766), com nome popular de jurará, é uma espécie bastante variá-

\footnotetext{
${ }^{1}$ Received on January 31, 2009.

Accepted for publication on July 4, 2009.

2 Postgraduate student in Veterinary Science, Universidade Estadual do Maranhão (UEMA), Cidade Universitária Paulo VI, Tirirical, Cx. Postal 9, São Luís, MA 65055-310, Brazil. *Autor para correspondência: franc.borges@yahoo.com.br

${ }^{3}$ Disciplina Diagnóstico por Imagem, Curso de Medicina Veterinária, Universidade Federal do Piauí (UFPI), Campus Cinobelina Elvas, BR 125 Km 3, Planalto Cibrazem, Bom Jesus, PI 64900-000, Brazil.

${ }^{4}$ Médica Veterinária Autônoma, Rua 4, C-10, Q-10, Cohatrac III, São Luís, MA 65052-100.

${ }^{5}$ Departamento das Clínicas, Curso de Medicina Veterinária,UEMA, São Luís, MA.
}

vel, e muitos nomes diferentes são atribuídos às suas populações, de acordo com sua localização geográfica. Atualmente, quatro subespécies foram validadas como $K$. scorpioides surgindo desde o extremo Sul do Panamá e norte da América do Sul, podendo ser encontradas ainda no Equador, no norte do Peru, sul da Bolívia, norte da Argentina, leste da Guiana e no Brasil. Desde modo, foi realizado um estudo ultrassonográfico e radiológico, a fim de descrever a morfologia e o desenvolvimento dos ovos de $K$. scorpioides em cativeiro, utilizando-se 20 fêmeas, no período de setembro de 2005 a agosto de 2006. No primeiro mês, o ciclo ovariano foi caracterizado pela ausência de folículos vitelogênicos, atrésicos ou presença de ovos em ovidutos. De outubro de 2005 a março de 2006 a varredura ultrassonográfica permitiu determinar o crescimento vitelogênico dos folículos, os quais foram observados com um formato que 
variou de ovóide a esférico, envolvidos por um conteúdo ecogênico, uma camada não-ecogência de albumina e uma casca de elevada ecogenicidade. Ovos presentes em ovidutos foram identificados por radiografias apenas 180 dias após início do experimento, quando a casca tornou-se suficientemente mineralizada para impressionar o filme radiográfico. Um transdutor linear de $7,5 \mathrm{MHz}$ promoveu imagens com resolução e penetração adequada para visibilização de folículos. Exames ultrassonográficos sucessivos em fêmeas $K$. scorpioides permitiram determinar os estágios iniciais de desenvolvimento de folículos vitelogênicos e o exame radiográfico mostrou-se como técnica simples para avaliar a presença de ovos em ovidutos, permitindo fazer inferências sobre desenvolvimento de ovos em jurarás, a partir dos 6 meses de pós-observação por ultrassonografia.

TERMOS DE INDEXAÇÃO: Kinosternon scorpioides, jurará, tartarugas, vida selvagem, conservação, reprodução.

\section{INTRODUCTION}

The turtle Kinosternon scorpioides (Linnaeus, 1766) is a quite variable species and many different names have been applied to populations throughout its range. Currently, however, four subspecies are considered valid. K. scorpioides ranges from southern Panama over most of northern and south America, being found in Ecuador, northern Peru, southern Bolivia, and northern Argentina, eastward to the Guyanas and in Pará and Maranhão State, Brazil, called there mucuã and jurará, respectively (Cabrera \& Colantonio 1997).

Currently, research has shown great concern with the conservation of jurará ( $K$. scorpioides) in the 'Baixada Ocidental Maranhense', a region where the reproductive age of this species can vary in different populations or localities. A decrease in population has been observed as a negative impact due to illegal hunting (Forero-Medina et al. 2007).

According to Mesen \& Cruz (1993), the sexual maturity is attained earlier than compared with other mud turtles, although the beginning of sexual maturity might be related more with the female size than the age of these animals. But the age of first reproduction still remains little known.

Ultrasonographic examination is a rapid and noninvasive technique to study soft tissues in wild animals (Sousa 2004, Alves et al. 2007). Image diagnostic of oviducal egg formation has already been advanced our knowledge about reproductive physiology and ecology of reptilians (Schramm et al. 1999). Reports of application of radiological techniques in reptile species were previously described by Wilkinson \& Gibbons (2005) and Wyneken et al. (2007).

On the other hands, the wide variety of reptiles has been demanded efforts to understand particular features of the normal anatomy in species with economic and conservational value.

This paper describes the ultrasonographic and radiographic features of the development of Kiosternon scorpioides eggs in the coelomic cavity, and aims to determine biometric rating of female mud turtles maintained in captivity.

\section{MATERIALS AND METHODS}

From September 2005 to August 2006, twenty female jurará mud turtles (Kinosternon scorpioides), maintaianed at the Nucleus of Studies and Preservation of Wild Animals, College of Veterinary Medicine, Maranhão State University, were examined by ultrasound on every eight days until the end of the study. These animals were divided into two experimental groups of 10 animals each. Group 1 was constituted by turtles with shell length less than $10 \mathrm{~cm}$, and Group II was constituted by mud turtles up to $10 \mathrm{~cm}$ length. Ultrasonographic and radiographic exams, as well as body measurements [length $(\mathrm{cm}) /$ weight $(\mathrm{g})$ ] were performed with all evaluated animals. Only clinically healthy animals were included in the study.

\section{Ultrasonographic exams}

The ultrasonographic procedure was accomplished with the animal in dorsal decumbency, and the hindlimb, ipsilateral to the ovary, extended and properly immobilized. Then, a $7.5 \mathrm{MHz}$ transducer probe was enough to access organs of the coelomic cavity in the species studied. A coupling gel was placed against the soft tissue of the inguinal region, and the scanning was performed orienting the probe in a craniolateral direction. No sedation was required for the examination.

\section{Radiographic exams}

Ventrodorsal radiographies were taken with the animals manually restrained and positioned in dorsal recumbency. Radiographic images were taken with an 8016HF Portable Xray Unit at a focal distance of $80 \mathrm{~cm}$, and technique factors varying about $40 \mathrm{kVp} / 0,1 \mathrm{~s}$. All images were analyzed with Adobe Photoshop CS. No sedation was necessary for the examination. The anatomic terminology applied corresponds to that of the Nomina Anatomica Veterinaria 2005. However, specific terminology for turtles and sea turtles was also applied.

\section{Statistical analyses}

Statistical design was obtained through the Pearson's Correction using SAS 6.04 statistical package (SAS Institute, Cary, NC, USA). The results were expressed as means and standard deviations, considering the error probability level of 0.05 .

\section{Vitellogenesis and nesting cycle}

From September 2005 to August 2006, the females were scanned by ultrasonography and $\mathrm{x}$-ray to explore the ovarian cycle of Kinosternon scorpioides. In the first month, the ovarian cycle was characterized by absence of vitellogenic follicles, atresic follicles or oviduct eggs through ultrasonographic and $\mathrm{x}$-ray examination, showing that mud turtles might be in gonadal inactive during this period.

Ultrasonographic scanning allowed to show growing vitellogenic follicles, from October 2005 to March 2006 on and to assess essential reproductive events, as development of preovulatory follicles. Calcium deposition of eggs was accessed by ultrasonography and $\mathrm{x}$-ray from April to August 2006, a period which coincides with the end of the 
Table 1. Average values and standard deviation of the biometrics of Kinosternon scorpioides in Groups I and II at the end of study

\begin{tabular}{|c|c|c|c|c|c|c|}
\hline \multirow[t]{2}{*}{ Group } & \multicolumn{2}{|c|}{ Carapace } & \multicolumn{2}{|c|}{ Plastron } & \multirow{2}{*}{$\begin{array}{l}\text { Height } \\
\text { Height }\end{array}$} & \multirow{2}{*}{$\frac{\text { Weight }}{\text { Weight }}$} \\
\hline & Length & Wide & Length & Wide & & \\
\hline Group I & $12,43 \pm 0,32$ & $8,44 \pm 0,37$ & $11,54 \pm 0,28$ & $6,58 \pm 0,24$ & $4,43 \pm 0,34$ & $292,87 \pm 31,99$ \\
\hline
\end{tabular}

rainy and beginning of the dry season. No previtellogenic phase was observed as ovarian follicles were small enough to be detected by ultrasonography. To show oviductal eggs by ultrasound and $x$ - ray was possible when the females reached a growing stage during the study, according to the measurements given in Table 1.

The nesting occurred three times per years. The first nesting season occurred from April to August 2006, about 8-20 days after the oviduct eggs were identified for the first time by radiography. Because ovarian follicles at different development stages were observed 17 days after

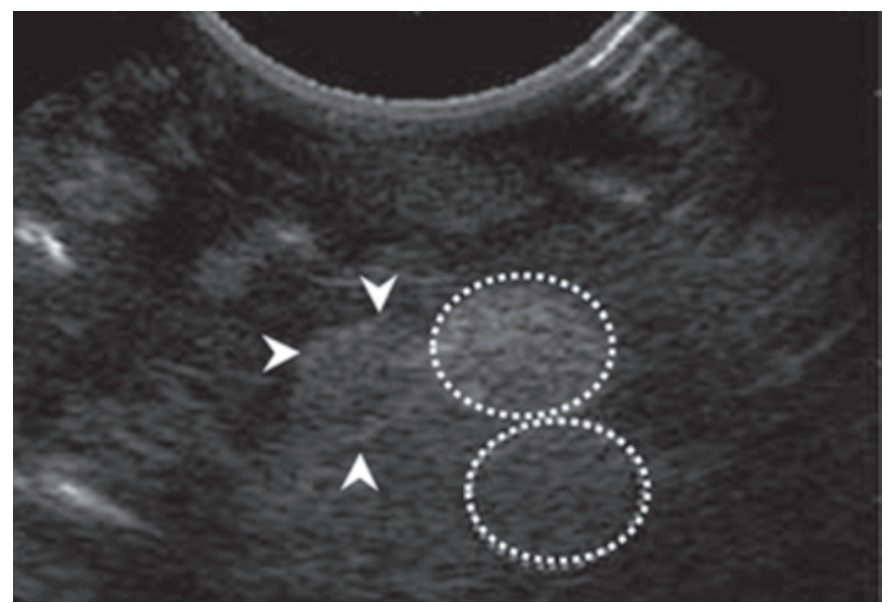

Fig.1. Ultrasonographic image of jurará (Kinosternon scorpioides). Note the vitellogenic follicles were observed with spherical to ovoid shapes surrounding by an echogenic yolk and albumin layer.

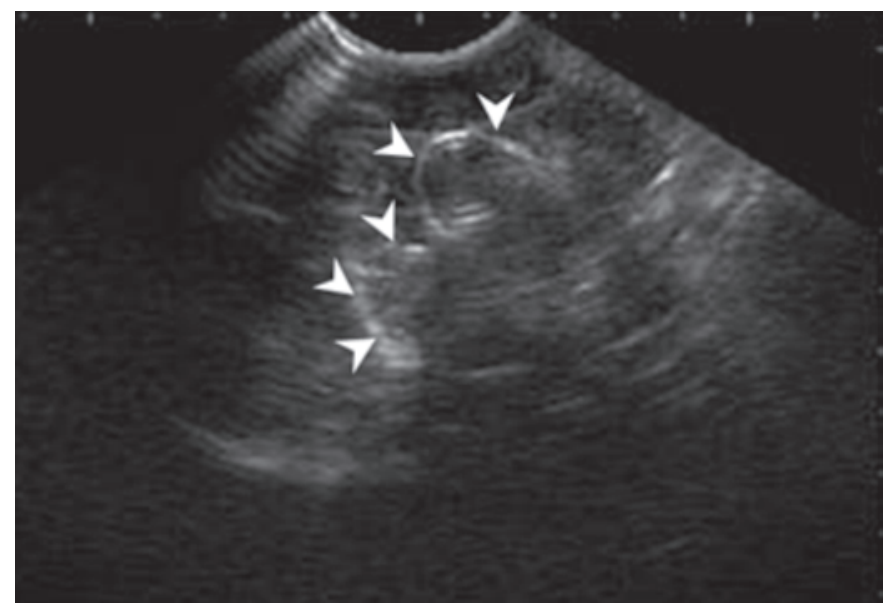

Fig.2. Ultrasonographic image of jurará- Kinosternon scorpioides. Increased acoustic shadowing with development of the shell results in decrease of the internal echogenic visualization of yolk and albumin layers. nesting, and new oviduct eggs could be seen by adequate radiographic technique.

\section{Ultrasonographic and radiographic appearance of oviduct eggs}

Vitellogenic follicles were observed with spherical to ovoid shapes, with a surrounding echogenic yolk and an
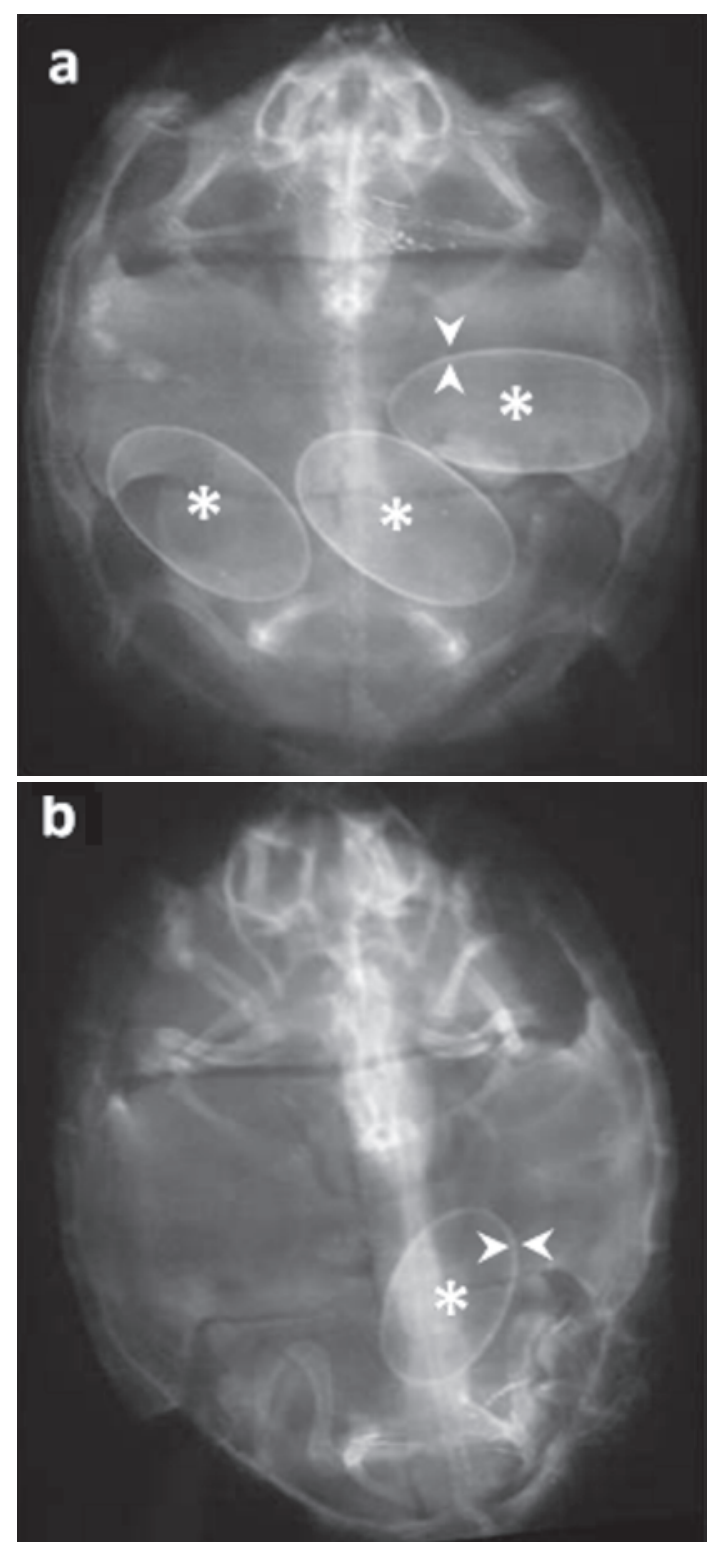

Fig.3. (a) Eggs of jurará (Kinosternon scorpioides)* identified by radiography 180 days after beginning the experiment. (b) This characteristic was observed when the shell (arrows) became enough mineralized to impress the radiographic film. 

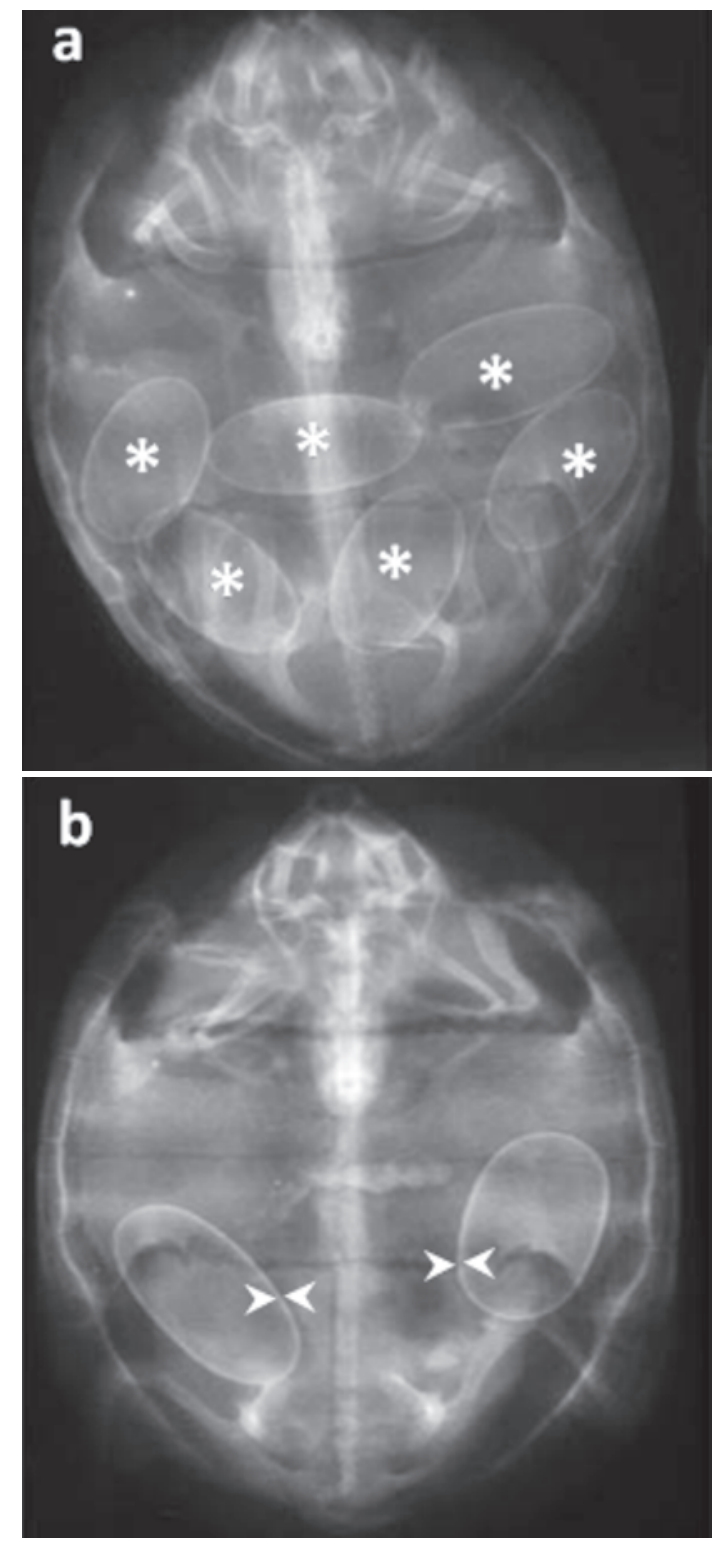

Fig.4. (a) The eggs $\left(^{*}\right)$ in the oviduct of jurará (Kinosternon scorpioides) appear oval-shaped, outlined with a regular shell. (b) Shell thickness varied according to different levels of mineralization (arrows).

albumin layer (Fig.1). Ultrasound measurements vary depending on the diameter of ultrasonic access. The shell became increasingly echogenic according to the mineralization process. Acoustic shadowing increased with shell development (Fig.2). This process resulted in a decrease of echogenic visualization of the yolk and albumin layers. The acoustic shadowing by the eco-dense shell turns it difficult to reveal the egg images, and the limited access to the inguinal area was a problem for precise measurement of the eggs.

The oviduct eggs were identified by radiographies just 180 days after beginning the experiment, when the shell becomes enough mineralized to impress the radiographic film (Fig.3a,b). Examination by radiography allowed to characterize the eggs as oval-shaped, outlined with a regular shell, and which thickness varied according to the different levels of shell mineralization (Fig.4a,b).

\section{Measurement of the eggs and weight}

The eggs were collected after the nesting and measures were taken. No significant correlation was verified among the egg measurements with the following biometric pattern of mud turtles: plastron length, width of plastron and height of mud the turtle. On the other hand, significant correlation $(p<0.05)$ was verified between the egg weight, its length and width. Significant correlation was verified between the egg width and its length to the width of the carapace, as well as to the weight of the animal.

\section{DISCUSSION}

The Kinosternon scorpioides ovarian cycle in captivity was characterized by absence of vitellogenic follicles, atresic follicles, and oviduct eggs, from September to October 2005. However, there have been few evidences for this characteristic in reptil species, according to Iverson (1979), Iverson et al. (1991), Redrobe \& Scudamore (2000) and Hellgren et al. (2000).

On the other hand, ovarian and folliculogenic activity in the reproductive cycle of Graeca terrestris was observed by Schildger (1996) and Lapid et al. (2004) throughout the year, and no seasonal variation was found for this species.

Evidences of folliculogenic development observed from October to March 2006 were also described by Iverson (1979), Iverson et al. (1991) and Shelby et al. (2000) in their ultrasonographic scanning of the coelomic cavity of Graptemys flavimaculata, as a pre-ovulatory wave, showing follicles about $15 \mathrm{~mm}$ of diameter. The largest follicles were identified between May $(28 \%, n=43)$ and June $(35 \%, n=17)$, respectively. Just 17 percent of females had a calcified shell.

In Galápagos tortoise Casares et al. (1997) and Rostal et al. (1998) demonstrated vitellogenic follicles with the size ranging from 28 to $42 \mathrm{~mm}$ of diameter. In the determination of estrogen seric values for sea turtles, these authors performed 247 ultrasonographic examinations, without distinction of vitellogenic follicles. According to observations made by Robeck et al. (1990), Penninck et al. (1991) and Wilkinson \& Gibbons (2005), the accurate assessment of echogenicity or observation pattern of follicles arose with hormonal floating, reproductive physiological activity, and environmental or behavior data. Taking all these data together, frequently they are able to generate subsidies for acquiring images, capable to be differentiated by ultrasonography.

Hyperechogenic and ovoid follicles in jurarás showed different characteristics from that predicted by Valente et al. (2007) and Silverman \& Janssen (1996), when detected by ultrasound in echogenic central regions of follicles in Caretta caretta turtles. Nevertheless, as described by Rostal et al. (1990) and Casares et al. (1997), sea turtles could present follicles with an anechoic medullary pattern, taking 95 percent of the volume of the follicle. 
The seasonality observed in the nesting occurred from May to August 2006. Specially retained eggs were still monitored in the coelomic cavity of some females throughout September 2006. This report is compatible with descriptions made by Loehr et al. (2004) and Shelby et al. (2000) in the South African Homopus signatus, verifying a seasonal tendency for increase in egg production during summer, when the weather is hot and dry. In Brazil, this aspect was first described in captive $K$. scorpioides by Castro (2006). The nesting has been characterized by this author from May to September and the highest rate of nesting was from June to July.

According with descriptions of Loehr et al. (2004), radiographic identification of eggs in the coelomic cavity is linked to the capacity of calcium deposition in the shell. In this experiment, the visualization of oviduct eggs just 180 days after ultrasonographic evaluation suggests the presence of vitellogenic follicles at different phases of development, as was observed in morphophysiological studies of Galápagos turtles by Robeck et al. (1990), Rostal et al. (1998), Schumacher \& Toal (2001) and Wilkinson et al. (2005).

Oviduct eggs with a calcified shell just 17 to 20 days after nesting have been favored the hypothesis about follicles at different development stages, and also revealed the high potential for egg shell deposition in K. scorpioides. This phase revealed egg shells with different levels of calcification.

In the same way, Robeck et al. (1990), Robeck et al. (1998), Rostal et al. (1998) and Redrobe \& Scudamore (2000) showed through hormone measurement serum calcium levels increase from the late nesting season to the mating season, which then declined in the nesting season. However, this increase was not statistically significant. Such finding allowed us to suggest the nesting moment in this species, because of the increasing radioopacity promoted by calcium deposition in the egg shell, which becomes more sensible to $x$-ray beam.

\section{CONCLUSIONS}

The $7.5 \mathrm{MHz}$ linear probe provided images with adequate resolution and penetration for visualization of follicles.

Successive ultrasonographic examinations of 20 Kinosternon scorpioides females allowed to access initial stages of developing vitellogenic follicles and oviduct eggs.

Although radiographic examination showed to be an easy technique to assess oviduct eggs, ultrasonography allowed to reveal egg development in jurarás from 6 months on.

\section{REFERENCES}

Alves F.R., Costa F.B., Arouche M.M.S., Barros A.C.E., Miglino M.A., Vulcano L.C. \& Guerra P.C. 2007. Ultrasonographic evaluation of the urinary system, liver and uterus of Cebus apella monkey. Pesq. Vet. Bras. 27(9):377-382.

Cabrera M.R. \& Colantonio S.E. 1997. Taxonomic revision of the South American subspecies of the turtle Kinosternon scorpioides. J. Herpet. 31(4):507-513.

Casares M., Rubel A. \& Honegger R.E. 1997. Observations on the female reproductive cycle of captive giant tortoises (Geochelone spp.) using ultrasound scanning. J. Zoo Wildl. Med. 28(3):267-273.

Castro A.B. 2006. Biologia reprodutiva do muçuã Kinosternon scorpioides (Linnaeus, 1776) em cativeiro. Dissertação de Mestrado, Curso de Pós-Graduação em Ciência Animal, Universidade Rural da Amazônia, Belém. 100p.

Forero-Medina G., Castano-Mora O.V. \& Montenegro O. 2007. Abundance, population structure, and conservation of Kinosternon scorpioides albogulare on the Caribbean island of San Andres, Colombia. Chelonian Conservation and Biology 6(2):163-169.

Hellgren E.C., Kazmaier R.T., Ruthven D.C. \& Synatzske D.R. 2000. Variation in tortoise life history: Demography of Gopherus berlandieri. Ecology 81(5):1297-1310.

Iverson J.B. 1979. Reproduction and growth of the mud turtle, Kinosteron subrubrum (Reptilia, Testudines, Kinosternidae), in Arkansas. J. Herpet. 13(1):105-111.

Iverson J.B. 1991. Life-history and demography of the yellow mud turtle, Kinosternon flavescens. Herpetol. 47(4):373-395.

Lapid R., Nir I., Snapir N. \& Robinzon B. 2004. Reproductive traits in the spur-thighed tortoise (Testudo graeca terrestris): New tools for the enhancement of reproductive success and survivorship. Theriogenology 61:1147-1162.

Loehr V.J.T., Henen B.T. \& Hofmeyr M.D. 2004. Reproduction of the smallest tortoise, the Namaqualand speckled padloper, Homopus signatus signatus. Herpet. 60(4):444-454

Mesen R.A.A. \& Cruz B.M. 1993. Sexual dimorphism of Kinosternonscorpioides (Testudines, Kinostermidae) in Palo-verde, Costa-rica. Revta Biologia Tropical 41(2):261-265.

Penninck D.G., Stewart J.S., Paul-Murphy J. \& Pion P. 1991. Ultrasonography of the California desert tortoise (Xerobates agassizi): Anatomy and application. Vet. Radiol. 32:112-116.

Redrobe S.P. \& Scudamore C.L. 2000. Ultrasonographic diagnosis of pericardial effusion and atrial dilation in a spur-thighed tortoise (Testudo graeca). Vet. Rec. 146(7):183-185.

Robeck T.R., Rostal D.C., Burchfield P.M., Owens D.W. \& Kraemer D.C. 1990. Ultrasound imaging of reproductive-organs and eggs in galapagos tortoises, Geochelone elephantopus. Zoo Biology 9(5):349359.

Robeck T.R., McBain J.F., Mathey S. \& Kraemer D.C. 1998. Ultrasonographic evaluation of the effects of exogenous gonadotropins on follicular recruitment and ovulation induction in the Atlantic bottlenose dolphin (Tursiops truncatus). J. Zoo Wildl. Med. 29(1):613.

Rostal D.C., Robeck T.R., Owens D.W. \& Kraemer D.C. 1990. Ultrasound imaging of ovaries and eggs in Kemp's Ridley sea turtles (Lepidochelys kempi). J. Zoo Wildl. Med. 21:27-35.

Rostal D.C., Owens D.W., Grumbles J.S., Mackenzie D. \& Amoss M.S. 1998. Seasonal reproductive cycle of the Kemp's Ridley sea turtle (Lepidochelys kempi). Gen. Comp. Endocrinol. 109:232-243.

Schildger B.J., Tenhu H., Kramer M., Casares M., Gerwing M., Geyer B., Rubel A. \& Isenbugel E. 1996. [Ultrasonic studies in reptiles]. Berl. Münch. Tierärztl Wochenschr. 109(4):136-141.

Schramm B.G., Casares M. \& Lance V.A. 1999. Steroid levels and reproductive cycle of the Galapagos tortoise, Geochelone nigra, living under seminatural conditions on Santa Cruz Island (Galapagos). Gen Comp. Endocrinol. 114:108-120. 
Schumacher J. \& Toal R.L. 2001. Advanced radiography and ultrasonography in reptiles. Seminars in Avian and Exotic Pet Medicine 10:162-168.

Shelby J.A., Mendonca M.T., Horne B.D. \& Seigel R.A. 2000. Seasonal variation in reproductive steroids of male and female yellow-blotched map turtles, Graptemys flavimaculata. Gen. Comp. Endocrinol. 119(1):43-51.

Silverman S. \& Janssen D. 1996. Diagnostic imaging, p.258-264. In: Mader D.R. (Ed.), Reptile Medicine and Surgery. W.B. Saunders, Philadelphia,

Souza F.L. 2004. Uma revisão sobre padrões de atividade, reprodução e alimentação de cágados brasileiros (Testudines, Chelidae). Phyllomedusa 3(1):15-27.

Valente A.L., Parga M.L., Espada Y., Lavin S., Alegre F., Marco I. \& Cuenca R. 2007. Ultrasonographic imaging of loggerhead sea turtles (Caretta caretta). Vet Rec. 161(7):226-232.

Wilkinson L.R. \& Gibbons J.W. 2005. Patterns of reproductive allocation: Clutch and egg size variation in three freshwater turtles. Copeia (4):868879.

Wyneken J., Epperly S.P., Crowder L.B., Vaughan J. \& Esper K.B. 2007. Determining sex in posthatchling loggerhead sea turtles using multiple gonadal and accessory duct characteristics. Herpet. 63(1):19-30. 